\title{
Sea level trend and variability in the Singapore Strait
}

\author{
P. Tkalich ${ }^{1}$, P. Vethamony ${ }^{2}$, Q.-H. Luu ${ }^{1}$, and M. T. Babu ${ }^{2}$ \\ ${ }^{1}$ Tropical Marine Science Institute, National University of Singapore, 14 Kent Ridge Road, 119227, Singapore \\ ${ }^{2}$ National Institute of Oceanography, Council of Scientific and Industrial Research, Dona Paula, Goa, 403004, India \\ Correspondence to: P. Tkalich (tmspt@nus.edu.sg)
}

Received: 16 May 2012 - Published in Ocean Sci. Discuss.: 15 June 2012

Revised: 14 September 2012 - Accepted: 4 February 2013 - Published: 8 March 2013

\begin{abstract}
Sea level in the Singapore Strait (SS) exhibits response to various scale phenomena, from local to global. Longest tide gauge records in SS are analysed to derive local sea level trend and annual, inter-annual and multi-decadal sea level variability, which then are attributed to regional and global phenomena. Annual data gaps are reconstructed using functions correlating sea level variability with ENSO. At annual scale, sea level anomalies in SS are (quasi-periodic) monsoon-driven, of the order of $\pm 20 \mathrm{~cm}$, the highest during northeast monsoon and the lowest during southwest monsoon. Interannual regional sea level drops are associated with El Niño events, while the rises are correlated with La Niña episodes; both variations are in the range of $\pm 5 \mathrm{~cm}$. At multidecadal scale, annual measured sea levels in SS are varying with global mean sea level, rising at the rate $1.2-1.7 \mathrm{~mm} \mathrm{yr}^{-1}$ for 1975-2009, 1.8-2.3 $\mathrm{mm} \mathrm{yr}^{-1}$ for 1984-2009 and 1.9$4.6 \mathrm{~mm} \mathrm{yr}^{-1}$ for 1993-2009. When SS rates are compared with the global trends $\left(2.0,2.4\right.$ and $2.8 \mathrm{~mm} \mathrm{yr}^{-1}$, respectively) derived from tide gauge measurements for the same periods, they are smaller in the earlier era and considerably larger in the recent one. Taking into account the first estimate of land subsidence rate, $1-1.5 \mathrm{~mm} \mathrm{yr}^{-1}$ in Singapore, the recent trend of absolute sea level rise in SS follows regional tendency.
\end{abstract}

\section{Introduction}

The South China Sea (SCS) is the largest semi-enclosed marginal sea in the northwest Pacific Ocean, bounded by 99 $122^{\circ} \mathrm{E}$ and $0-25^{\circ} \mathrm{N}$. It consists of a deep basin with two continental shelves along the north and southwest coasts. SCS is connected to the East China Sea through the Taiwan Strait, to the Pacific Ocean through the Luzon Strait, and to the Java
Sea through the Karimata Strait (Fig. 1a). Astronomic tides propagate in the SCS through Luzon Strait, and there are several amphidromic points in the continental shelves of SCS (Fang et al., 1999; Ko et al., 2008).

Singapore Strait (SS) is situated in the middle of Sunda Shelf, encompassed by SCS and Malacca Strait. SS is connected through SCS to the Pacific Ocean on the east, and to the Indian Ocean via the Malacca Strait on the west. Water transport in SS is in the order of 0.1 to $0.2 \mathrm{~Sv}$ from east to west, a minor component of the Indonesian Throughflow (Wannasingha et al., 2003). The water depth of SS ranges between $30 \mathrm{~m}$ and $120 \mathrm{~m}$.

It is generally expected that sea level in the Singapore Strait is governed by various scale phenomena, from global to local. Global signals are due to climate change and variability, having a typical temporal scale of the order of decades to centuries. At regional scale, annual and interannual sea level variabilities are caused by the Asian monsoon system, modulated by coupled ocean-atmosphere oscillations, such as El Niño-Southern Oscillation (ENSO). At local (hourly) scale, sea level elevation is driven by astronomic tides distorted by bathymetry gradients.

Long-term global mean sea level (MSL) trends have been estimated by several researchers (e.g., Douglas, 1991; Cabanes et al., 2001; White et al., 2005; Church et al., 2001, 2011; Bindoff et al., 2007; Becker et al., 2011; Hamlington et al., 2011; Meyssignac and Cazenave, 2012; Meyssignac et al., 2012a, b). While the global linear trend from 1901 to 2009 was found to be $1.7 \pm 0.2 \mathrm{~mm} \mathrm{yr}^{-1}$, the highest rate of MSL rise in recent decades (since 1990's) is found to be $3.3 \pm 0.4 \mathrm{~mm} \mathrm{yr}^{-1}$ from the satellite data (Nicholls and Cazenave, 2010) and $2.8 \pm 0.8 \mathrm{~mm} \mathrm{yr}^{-1}$ from the in situ data (Church and White, 2011), as summarized in Table 1. 
Table 1. Linear trends of sea level rise $\left(\mathrm{mm} \mathrm{yr}^{-1}\right)$ over selected periods.

\begin{tabular}{|c|c|c|c|c|}
\hline \multirow[t]{2}{*}{ Source of record } & \multirow[t]{2}{*}{ Trend (entire available period) } & \multicolumn{3}{|c|}{ Periods } \\
\hline & & 1975-2009 & 1984-2009 & 1993-2009 \\
\hline Global - Tide gauge ${ }^{(1)}$ & $1.7 \pm 0.2(1900-2009)$ & $2.0 \pm 0.3$ & $2.4 \pm 0.4$ & $2.8 \pm 0.8$ \\
\hline Global - Altimetry & $3.1 \pm 0.4(1993-2012)$ & $\mathrm{NA}^{(4)}$ & $\mathrm{NA}^{(4)}$ & $3.3 \pm 0.4^{(3)}$ \\
\hline Tanjong Pagar (TP) & $3.1 \pm 0.8(1984-2011)$ & $\mathrm{NA}^{(4)}$ & $2.3 \pm 0.9$ & $4.6 \pm 1.2$ \\
\hline Raffles Lighthouse (RL) & $1.8 \pm 0.4(1975-2011)$ & $1.2 \pm 0.4$ & $2.1 \pm 0.6$ & $3.0 \pm 1.3$ \\
\hline Sultan Shoal (SH) & $2.1 \pm 0.4(1973-2011)$ & $1.7 \pm 0.4$ & $2.4 \pm 0.7$ & $1.9 \pm 1.4$ \\
\hline Sembawang (SE) & $1.5 \pm 0.4(1973-2011)$ & $1.3 \pm 0.4$ & $1.8 \pm 0.7$ & $3.9 \pm 1.3$ \\
\hline Singapore Strait average & $2.9 \pm 0.6(1984-2011)$ & $\mathrm{NA}^{(4)}$ & $2.1 \pm 0.6$ & $3.4 \pm 1.3$ \\
\hline
\end{tabular}

${ }^{1}$ Church and White (2011); ${ }^{2}$ Nerem et al. (2010); ${ }^{3}$ Nicholls and Cazenave (2010); ${ }^{4}$ not available.
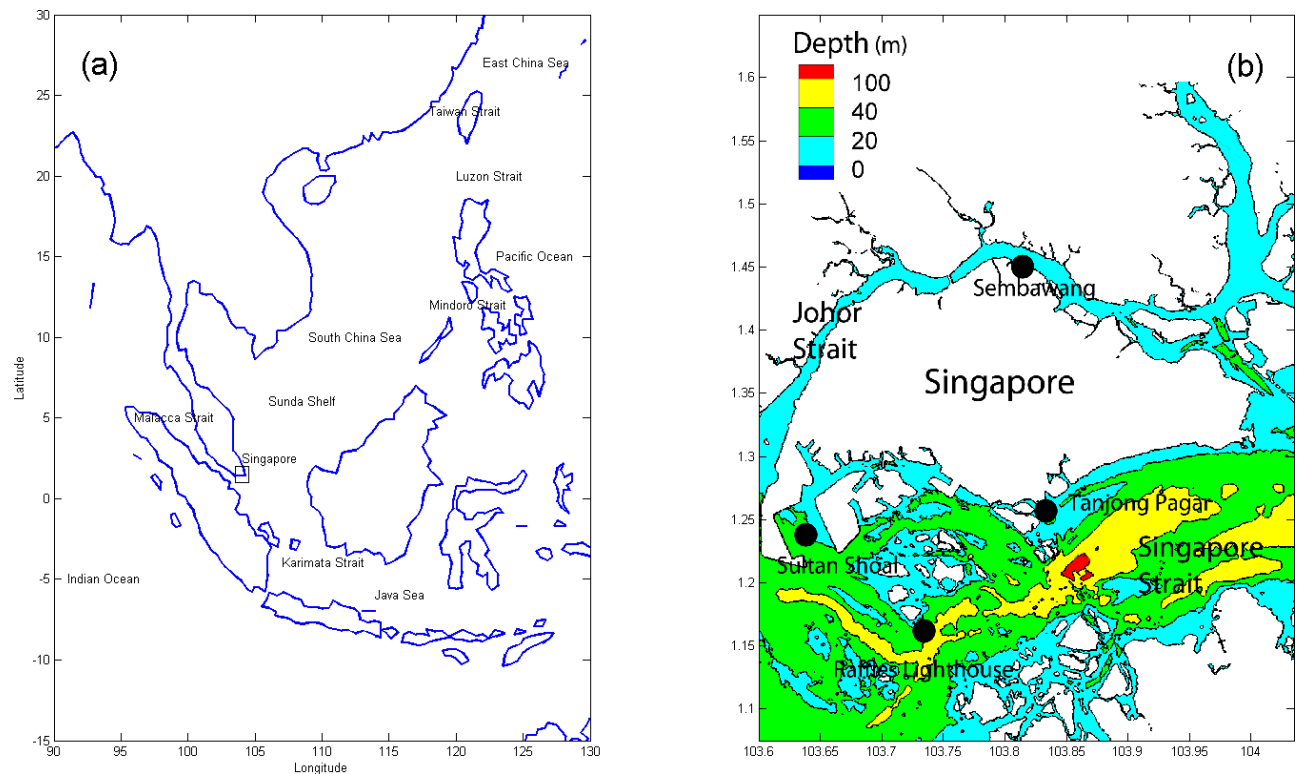

Fig. 1. (a) Study area. (b) The Singapore Strait and its vicinity (bathymetric contours are at 20, 40 and $100 \mathrm{~m}$ depths). Black symbols denote the locations of 4 tide gauges, namely Tanjong Pagar, Raffles Lighthouse, Sultan Shoal and Sembawang.

Similar or larger recent MSL rise rates have been observed in the western tropical Pacific, eastern Indian and Southern Ocean (Carton et al., 2005; Cheng and Qi, 2007; Unnikrishnan and Shankar, 2007). Church et al. (2004, 2006) have analysed the sea level rise in the region bounded by $40^{\circ} \mathrm{S}$ to $40^{\circ} \mathrm{N}$ and $30^{\circ} \mathrm{E}$ to $120^{\circ} \mathrm{W}$ (centered on Sunda Shelf), and found that the average upward trend for the period 1950 to 2001 was about $2 \mathrm{~mm} \mathrm{yr}^{-1}$; in particular, the region encompassing SS the MSL rise during the period 19552003 by Church et al. (2004) is $3.6 \mathrm{~mm} \mathrm{yr}^{-1}$, and for the ten year period after 1993 the regional sea level rise rate was about $4 \mathrm{~mm} \mathrm{yr}^{-1}$. For the Singapore area, the earlier rate was similar, but the later trend is somewhat higher, centered at $5 \mathrm{~mm} \mathrm{yr}^{-1}$. The larger regional trend since 1993 in the tropical Pacific and Indian Oceans has been attributed to considerable interannual and decadal sea level variability associated, respectively, with the ENSO and the North Pacific Decadal
Oscillation (Trenberth and Hurrell, 1994; Chambers et al., 2002; Church et al., 2004, 2006; and Becker et al., 2011).

In the South China Sea, some researchers have analysed sea level variability in the last 30 years using tide gauges and altimetry data (Li et al., 2002; Cheng and Qi, 2007; Rong et al., 2007). Tsimplis and Shaw (2008) suggested that local sea level rise is a combination of global sea level variability due to changes in water mass and density, as well as local and regional effects. It has been pointed out by several researchers (Qu et al., 2005, Rong et al., 2007, Yu et al., 2007) that in the SCS, the inflow of cold and salty Pacific water is through the Luzon Strait in boreal winter and outflow of warm and fresh water is through the Mindoro and Karimata Straits in summer, in accordance with the regimes of monsoon winds - termed as the South China Sea Throughflow (SCSTF). The SCS circulation coupled with atmospheric teleconnection is 
likely to be the cause for modulating the inter-annual sea level variability associated with ENSO.

On the Sunda Shelf and particularly in SS, our earlier study (Tkalich et al., 2012) showed that wind over the SCS is arguably the most important factor, which determines the observed annual variability in sea level anomalies (SLAs). SLAs in SS were found to be part of the basin-wide storm surges, of the order of $20 \mathrm{~cm}$, positive during northeast monsoon and negative during southwest monsoon. However, inter-annual and multi-decadal variability of sea level as well as sea level trend in SS are yet to be quantified.

In the present study, tide gauge records and satellite altimetry are used to analyse long-term sea level signals in the SS. Frequency analysis is performed to filter out astronomic tides from the tide gauge records, and SLAs obtained are correlated with global MSL as well as regional and global phenomena, including ENSO cycle and North Pacific Decadal Oscillation.

\section{Data and methodology}

There are 12 tide gauge stations in the Singapore and Johor Straits -8 stations along the coast of Singapore and 4 offshore. We used the data of four research-quality stations, namely, Tanjong Pagar (TP), Raffles Lighthouse (RL), Sul$\tan$ Shoal (SH) and Sembawang (SE), each one having more than 25 years of long-term data and less data gaps compared to other stations (Fig. 1b). Annual, monthly and hourly sea level data for the stations are obtained or derived from the Permanent Service for Mean Sea Level (PSMSL, 2013) and University of Hawaii Sea Level Center (UHSLC, 2013). We truncated segments that have more than 5 years of discontinuity, thus, retaining SE and SH data for the period 19732011, as well as data from RL and TP stations for the periods 1975-2011 and 1984-2011, respectively. Even though TP station has data from 1974, the data before 1984 are sporadic.

In order to eliminate tidal constituents, the tide gauge data are subject to harmonic analysis using T_Tide program (Pawlowicz et al., 2002), and residuals (SLAs) are studied as shown in Fig. 2a for TP station. Satellite altimetry data from the merged global datasets (AVISO, 2013) at the closest point to TP tide gauge have been used to verify our analysis (Figs. $2 b$ and c). The algorithm used to detide sea level records is verified on PSMSL data, as shown in Fig. 2d. The average trend of sea level in SS is calculated as the arithmetic mean of four tide gauge records for the common period 1984-2009.

Annual sea level records in SS show variability with ENSO in the range $\pm 5 \mathrm{~cm}$, where drops are associated with El Niño events, while the rises are correlated with La Niña episodes (Fig. 4f). This observation helped to derive linear dependencies to fill a few data gaps, identified by open blue circles in Fig. 4a-d. The data reconstruction algorithm is ver- ified against satellite altimetry during the entire available period. In relating annual sea level records to ENSO events, the Multivariate ENSO Index (MEI, 2013) is used (Wolter and Timlin, 1993, 1998). It consists of six main variables (sealevel pressure, zonal and meridional components of the surface wind, sea surface temperature, surface air temperature and total cloudiness fraction of the sky), which have been observed over the tropical Pacific for many years.

\section{Trend and variability of sea level in Singapore Strait}

In the following sections, we explore sea level trend and variability in SS and illuminate signals of climate and ocean variability at different temporal and spatial scales.

\subsection{Role of Asian monsoon in creating seasonal sea level pattern}

The seasonal variability of SLAs at TP station for a typical year (2011) is presented in Fig. 2b. SLAs vary in the range of $\pm 20 \mathrm{~cm}$ throughout the year, yielding positive values (with respect to their annual mean) during NovemberFebruary (northeast monsoon, NE) and negative values during June-August (southwest monsoon, SW). Similar seasonal pattern is repeated every year during the considered period 1984-2012 (Fig. 2c), modulated by climate and weather variabilities. It has been pointed out by Tkalich et al. (2012) that the seasonal and extreme winds over SCS as well as their persistence and direction play the primary role in generating SLAs in SS.

To examine climatological annual patterns of SLAs in SS for the four tide gauge stations, we used monthly averaged values (Fig. 3). All stations show consistent climatology, but with different SLA magnitudes, for instance, SE and TP stations have the most prominent seasonal signals, whereas $\mathrm{SH}$ and RL exhibit the weakest anomalies. This difference could be due to the fact that SE and TP stations are located closer to the SCS, thus more exposed to the monsoon surge, whereas $\mathrm{SH}$ and RL gauges are shielded from the direct monsoonal force.

\subsection{Role of multi-decadal wind-driven circulation variability}

Church and White (2011) observed that there is considerable variability in the rate of MSL rise from 1880 to the present, most likely due to a multi-decadal climate oscillation. The local sea level rise rates peaked to over $2 \mathrm{~mm} \mathrm{yr}^{-1}$ in 1890's, 1940's, 1970's and nearly $3 \mathrm{~mm} \mathrm{yr}^{-1}$ in $1990 \mathrm{~s}$ due to a combination of climate change and climate variability, having $20-40$ yr cycle. Regionally, due to a strengthening of the Walker circulation generating a positive wind stress curl anomaly (Mitas and Clement, 2005; Tanaka et al., 2004), the subtropical gyre in the North Pacific expanded along its southern boundary over the past two decades. The 

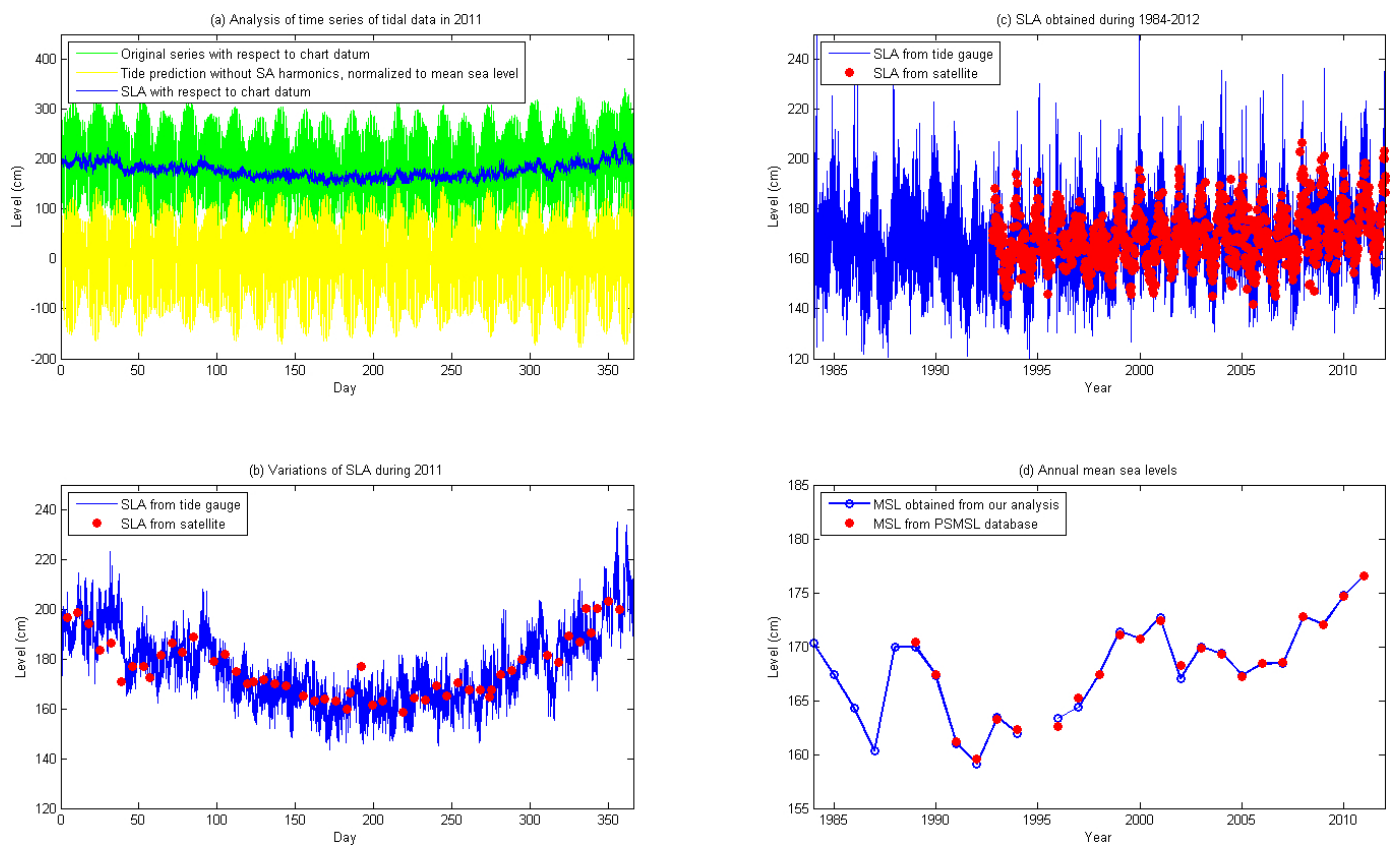

Fig. 2. Analysis of Tanjong Pagar tide station data: (a) Typical annual tide gauge record and derived sea level anomalies; Comparison of sea level anomalies derived from the tide gauge and satellite altimetry (AVISO) for (b) a typical year, and (c) the period 1984-2012; (d) Annual sea levels obtained in our analysis (blue lines) in accordance with these achieved in PSMSL database (red symbols).

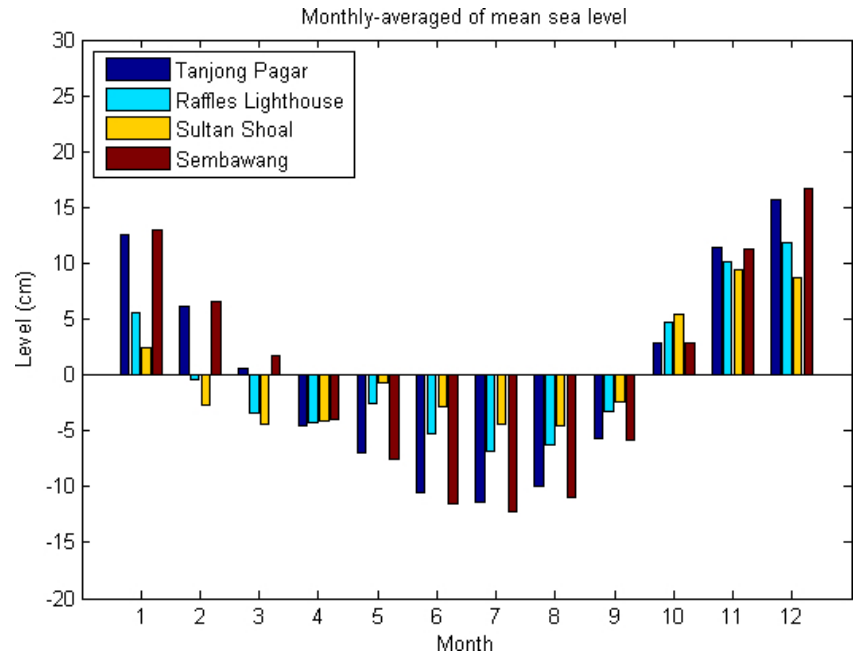

Fig. 3. Monsoonal and seasonal influence on sea level variations (monthly sea level anomalies).

North Equatorial Current shifted southward along the $137^{\circ} \mathrm{E}$ meridian (Qiu and Chen, 2012) leading to an increase in sea surface height east of the Philippines. Thus, regional wind stress curl anomaly is also responsible for the enhanced regional sea level rise, exceeding $10 \mathrm{~mm} \mathrm{yr}^{-1}$ in the western tropical North Pacific Ocean (Timmermann et al., 2010). Satellite altimetry data suggest that similar pattern has been established over the entire Sunda Shelf in the past $20 \mathrm{yr}$.
The spikes in averaged sea level in the SS due to the multidecadal variability are identified in Fig. 4.

\subsection{Role of ENSO in SS interannual sea level variability}

Figure $4 a-d$ bring out the interannual variability of sea level in SS during the observation periods. One can notice significant negative correlation (with a coefficient -0.7 ) between the MEI index and averaged annual sea level in SS (Fig. 4e, f) as well as similar order correlation with individual tide gauge annual records, indicated by numerals in Fig. $4 \mathrm{a}-\mathrm{d}$. The most prominent troughs in the annual sea level are observed during El Niño peaks in 1982-1983, 1987, 1992, 1997 and 2003, whereas sea level crests are evident during La Niña extremes in 1975, 1985, 1988, 1999 and 2008. It is clear that magnitude of sea level variability due to ENSO is proportional to MEI strength during the observation period. In particular, during the strongest El Niño/La Niña episodes, the sea level annual anomaly is the largest, of the order of $5-8 \mathrm{~cm}$ at TP, $3-5 \mathrm{~cm}$ at RL, $3-5 \mathrm{~cm}$ at $\mathrm{SH}$, and $3-8 \mathrm{~cm}$ at SE.

The exact mechanism of sea level dependence on ENSO is yet to be understood - most likely being a combination of direct signal propagation through ocean lateral fluxes and atmospheric teleconnection feedback. One should be careful in interpreting sea level trends with short period data during switches of ENSO or multi-decadal cycles. For example, between 1997 El Niño and 1999 La Niña years, sea level has risen by $8 \mathrm{~cm}, 10 \mathrm{~cm}, 12 \mathrm{~cm}$ and $12 \mathrm{~cm}$ at TP, RL, SH and SE, respectively. Indeed, Cheng and Qi (2007) analysed 

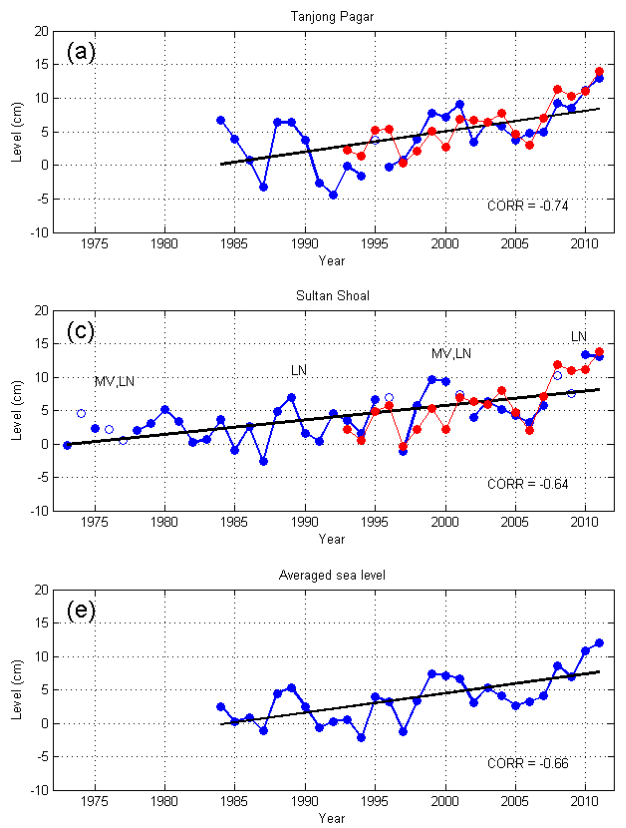
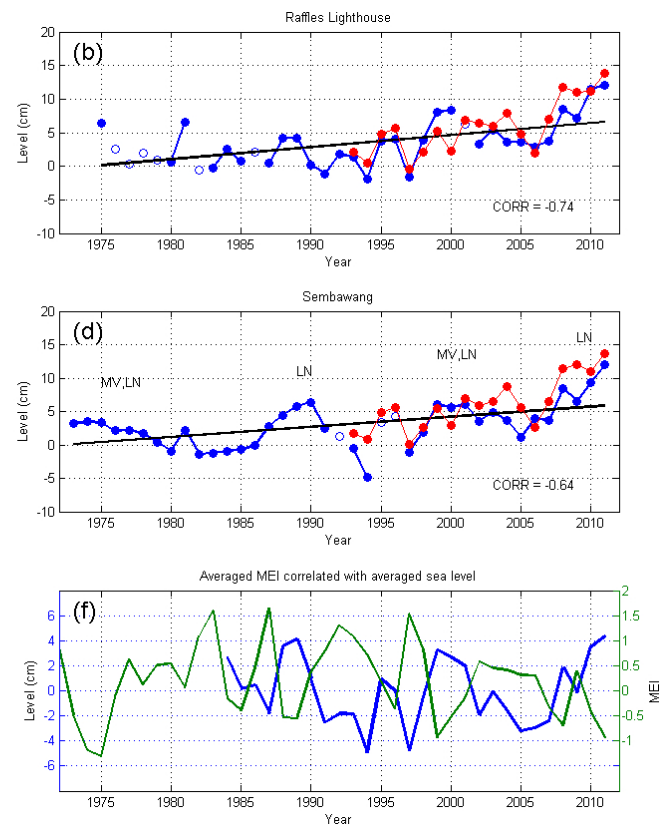

Fig. 4. (a-e) Sea level at tide gauges in Singapore Strait (the zero reference level is adjusted to the beginning of the regression line): blue dot-line identify annual sea level at the tide gauges, with linear trend for the observation period identified by solid black lines; open blue circles indicate restored missing data; correlation of sea level and Multivariate ENSO Index (MEI) is shown for each tide record; red dot-line identify satellite altimetry for the SS region (AVISO). (f) Comparison of anomalies of average annual SS sea level (detrended, blue line) with yearly-averaged MEI (green line). Periods of sea level maxima due to multi-decadal variability and La Niña episodes are indicated by symbols "MV" and "LN", respectively.

TOPEX/Poseidon altimetry for the SCS to show, in particular, that the MSL over the SCS has risen by $10 \mathrm{~cm}$ between 1997 and 1999. As shown in Fig. 2 of Church et al. (2006) that SS region also had a sea level rise of the order of 5$10 \mathrm{~mm} \mathrm{yr}^{-1}$ during 1993-2001, it is lower than or equal to our averaged SS sea level rise rate $10.0 \mathrm{~mm} \mathrm{yr}^{-1}$ for the same period. It is clear from the short-term analysis that to avoid misinterpretation of sea level trend influenced by ENSO and multi-decadal oscillation signals, the data span should be at least several decades long, preferably exceeding 50-60 years.

\subsection{Role of global signal in SS sea level trend}

Figure 4 and Table 1 provide comparison of trends obtained from tide gauges in SS with the global trends (Church and White, 2011) for the period 1973-2011 and shorter. Having a moderate start after 1975, SS sea level has increased rapidly till the year 2000. We presume that acceleration after 1993 is partially attributed to the ENSO cycle as well as to multidecadal climate variability, as indicated in Fig. 4(c,d). An additional possible mechanism behind the acceleration is the global-scale consequences of the eruption of Mt. Pinatubo in the Philippines in 1991 (Church et al. 2004; Church et al. 2005; Gregory et al., 2006; Domingues et al., 2008). Atmospheric ashes have slowdown warming of the Earth for two years, but the accumulated commitments have rebounded strongly after 1993. According to Holgate and Woodworth
(2004) during the period January 1993 to December 2002, the corrected tide gauge records provided a global average trend of $4.0 \mathrm{~mm} \mathrm{yr}^{-1}$.

\subsection{Sea level rise and variability in SS}

Globally, sea level rise has been accelerating of the order of $0.01 \mathrm{~mm} \mathrm{yr}^{-2}$ since 1870 (Church and White, 2006; Jevrejeva et al., 2008, Church and White, 2011) leading to the 20th century global sea level rise rate $1.7 \pm 0.2 \mathrm{~mm} \mathrm{yr}^{-1}$. This value could be compared with SS averaged rate $\left(1.8 \pm 0.4 \mathrm{~mm} \mathrm{yr}^{-1}\right)$ measured at SH and SE tide gauges but for the shorter period, 1973-2011. In particular, measured sea level in SS has been rising at the rate 1.8-2.3 (on an average of $2.1 \pm 0.6) \mathrm{mm} \mathrm{yr}^{-1}$ during 1984-2009 and 1.9-4.6 $(3.4 \pm 1.3) \mathrm{mm} \mathrm{yr}^{-1}$ for the period 1993-2009. When compared to global rates of $2.4 \pm 0.4$ and $2.8 \pm 0.8 \mathrm{~mm} \mathrm{yr}^{-1}$ for the same periods, respectively, it is clear that SS sea level rise had a relatively slow start in the early period, but accelerated faster than the global rate later. The sea level increased after 1993 most likely due to multi-decadal climate variability.

\section{Conclusion and discussion}

In summary, sea level trend and variability in SS have been studied using the data from four tide gauges, namely, Tanjong Pagar (TP), Raffles Lighthouse (RL), Sultan Shoal (SH) 
and Sembawang (SE). After tide signals are removed from the records, the residuals are analysed to uncover regional and global signals that might be affecting local sea level. At annual scale, sea level in SS is driven by monsoon wind causing a sea level surge of the order of $20 \mathrm{~cm}$, positive during NE monsoon and negative during SW monsoon. Interannual variability associated with ENSO cycle is expressed as dropping sea level during El Niño events and rising during La Niña episodes, both are of the order of $\pm 5 \mathrm{~cm}$. During 1984-2009, the average sea level rise in SS has accelerated to $2.1 \pm 0.6 \mathrm{~mm} \mathrm{yr}^{-1}$, almost reaching the global rate of $2.4 \pm 0.4 \mathrm{~mm} \mathrm{yr}^{-1}$. In recent years (1993-2009), the average SS sea level has risen at the rate of $3.4 \pm 1.3 \mathrm{~mm} \mathrm{yr}^{-1}$, exceeding the global trend of $2.8 \pm 0.8 \mathrm{~mm} \mathrm{yr}^{-1}$. SH seems to be an outlier during the recent period, having the lowest sea level rise rate of $1.9 \pm 1.4 \mathrm{~mm} \mathrm{yr}^{-1}$ among other stations (TP: $4.6 \pm 1.2 \mathrm{~mm} \mathrm{yr}^{-1}$, RL: $3.0 \pm 1.3 \mathrm{~mm} \mathrm{yr}^{-1}$, and SE: $3.9 \pm 1.3 \mathrm{~mm} \mathrm{yr}^{-1}$ ). This discrepancy might be due to the influence of intensive coastal development in the area (Lui and Tan, 2001). If SH tide gauge readings are discarded, the average SS sea level rise has an upward trend of $4.1 \pm 1.3 \mathrm{~mm} \mathrm{yr}^{-1}$ during the period 1993-2009.

In order to get an absolute rate of sea level rise in SS as opposed to measured relative sea level, tide gauge records have to be corrected for vertical land motion (VLM). VLM is a highly localised phenomenon, which primarily results from either glacial isostatic adjustment in areas covered by ice sheets, movement of the Earth's tectonic plates, or local compaction of sediment and underground soil. A few studies have been carried out using GPS measurements to derive the speed of crustal motions in regions adjacent to Singapore (Simons et al., 2007; Trisirisatayawong et al., 2011). However, no study has explicitly provided the VLM estimation for Singapore, except for a pilot investigation by Fernandes et al. (2011) who reported a uniform subsidence rate of 1$1.5 \mathrm{~mm} \mathrm{yr}^{-1}$ for the whole island using the limited observations for the period 2006-2011 via the newly established Singapore Satellite Positioning Reference Network (SiReNT). With the limited data available, if the correction is applied to the tide gauge records, Singapore Strait averaged sea level rise rate became closer to the regional MSL rise trend.

Acknowledgements. We thank the Directors of NIO, CSIR and TMSI, NUS for the facilities provided at their respective Institutes; and MPA for providing the data. P. Vethamony and M. T. Babu are thankful to NUS, Singapore for granting Visiting Research Fellowship. We also thank to A. S. Unnikrishnan, NIO, CSIR and X. Haihua, TMSI, NUS for giving useful suggestions; and acknowledge the anonymous reviewers for the critical comments, which helped us to improve the manuscript substantially.

Edited by: A. Sterl

\section{References}

AVISO, Altimetric data, Retrieved Jan 25, 2013, from http://www. aviso.oceanobs.com/en/data.html, 2013.

Becker, M., Meyssignac, B., Letetrel, C., Llovel, W., Cazenave, A., and Delcroix, T.: Sea level variations at tropical Pacific islands since 1950, Glob. Planet. Change, 80-81, 85-98, doi:10.1016/j.gloplacha.2011.09.004, 2011.

Bindoff, N. L., Willebrand, J., Artale, V, Cazenave, A., Gregory, J., Gulev, S., Hanawa, K., Le Quéré, C., Levitus, S., Nojiri, Y., Shum, C. K., Talley L. D., and Unnikrishnan, A.: Observations: Oceanic climate change and sea level, in: Climate Change 2007: The Physical Science Basis. Contribution of Working Group I to the Fourth Assessment Report of the Intergovernmental Panel on Climate Change, edited by: Solomon, S., Qin, D., Manning, M., Chen, Z., Marquis, M., Averyt, K. B., Tignor, M., and Miller, H. L., Cambridge Univ. Press, Cambridge, UK and New York, USA, 2007.

Cabanes, C., Cazenzve, A., and Le Provost, C.: Sea level rise during past 40 years determined from satellite and in situ observations, Science, 294, 840-842, doi:10.1126/science.1063556, 2001.

Carton, J. A., Giese, B. S., and Grodsky, S. A.: Sea level rise and the warming of the oceans in the Simple Ocean Data Assimilation (SODA) ocean reanalysis, J. Geophys. Res., 110, C09006, doi:10.1029/2004JC002817, 2005.

Chambers, D. P., Melhaff, C. A., Urban, T. J., Fuji, D., and Nerem, R. S.: Low-frequency variations in global mean sea level: 1950 2000, J. Geophys. Res., 107, 3026, doi:10.1029/2001JC001089, 2002.

Cheng, X. and Qi, Y.: Trends of sea level variations in the South China Sea from merged altimetry data, Glob. Planet. Change, 57, 371-382, doi:10.1016/j.gloplacha.2007.01.005, 2007.

Church, J. A., Gregory, J. M., Huybrechts, P., Kuhn, M., Lambeck, K., Nhuan, M. T., Qin, D., and Woodworth, P. L.: Changes in Sea Level, Intergovernmental Panel on Climate Change, Third Assessment Report, Cambridge Univ. Press, New York, 639-694, 2001.

Church, J. A., White, N. J., Coleman, R., Lambeck, K., and Mitrovica, J. X.: Estimates of the regional distribution of sea-level rise over the 1950 to 2000 period, J. Climate, 17, 2609-2625, doi:10.1175/1520-0442(2004)017;2609:EOTRDO $; 2.0 . C O ; 2$, 2004.

Church, J. A., White, N. J., and Arblaster, J. M.: Significant decadalscale impact of volcanic eruptions on sea level and ocean heat content, Nature, 438, Nov. 3, doi:10.1038/nature04237, 2005.

Church, J. A., White, N. J., and Hunter, J. R.: Sea-level rise at tropical Pacific and Indian Ocean islands, Glob. Planet. Change, 53, 155-168, doi:10.1016/j.gloplacha.2006.04.001, 2006.

Church, J. A. and White, N. J.: Sea-level rise from the late 19th to the early 21st Century, Geophys. Res. Lett., 33, L01602, doi:10.1029/2005GL024826, 2006.

Church, J. A., White, N. J., Konikow, L. F., Domingues, C. M., Cogley, J. G., Rignot, E., Gregory, J. M., van den Broeke, M. R., Monaghan, A. J., and Velicogna, I.: Revisiting the Earth's sea-level and energy budgets from 1961 to 2008, Geophys. Res. Lett., 38, L18601, doi:10.1029/2011GL048794, 2011.

Church, J. A. and White, N. J.: Sea-level rise from the late 19 th to the early 21st Century, Surv. Geophys., 32, 585-602, doi:10.1007/s10712-011-9119-1, 2011. 
Domingues, C. M., Church, J. A., White, N. J., Gleckler, P. J., Wijffels, S. E., Barker, P. M., and Dunn, J. R.: Improved estimates of upper-ocean warming and multidecadal sea-level rise, Nature, 453, 1090-1093, doi:10.1038/nature07080, 2008.

Douglas, B. C.: Global sea level rise, J. Geophys. Res., 96, 69816992, doi:10.1029/91JC00064, 1991.

Fang, G., Kwok, Y.-K., Yu, K., and Zhu, Y.: Numerical simulation of principal tidal constituents in SCS, Gulf of Tonkin \& Thailand, Cont. Shelf Res., 19, 845-869, doi:10.1016/S02784343(99)00002-3, 1999.

Fernandes, R. M. S., Raju, D., and Khoo, V.: Evaluation of the Tectonic Stability of Singapore based on SiReNT, Joint International Symposium on Deformation Monitoring, Hong Kong, Nov 4, 2011.

Gregory, J. M., Lowe, J. A., and Tett, S. F. B.: Simulated globalmean sea level changes over the last half-millennium, J. Climate, 19, 4576-4591, doi:10.1175/JCLI3881.1, 2006.

Hamlington, B. D., Leben, R., Nerem, S., Han, W., and Kim, K. Y.: Reconstructing sea level using cyclostationary empirical orthogonal functions, J. Geophys. Res., 116, C12015, doi:10.1029/2011JC00752, 2011.

Holgate, S. J. and Woodworth, P. L.: Evidence for enhanced coastal sea level rise during the 1990s, Geophys. Res. Lett., 31, L07305, doi:10.1029/2004GL019626, 2004.

Jevrejeva, S., Moore, J. C., Grinsted, A., and Woodworth, P. L.: Recent global sea level acceleration started over 200 years ago?, Geophys. Res. Lett., 35, L08715, doi:10.1029/2008GL033611, 2008.

Ko, D. S., Martin, P. J., Chao, S. Y., Shaw, P. T., and Lien, R. C.: Large-amplitude internal waves in the South China Sea, Ocean Sci. Tech. (Naval Res. Lab. Review), 197-200, 2008.

Li, L., Xu, J., and Cai, R.: Trends of sea level rise in the South China Sea during the 1990s: an altimetry result, Chin. Sci. Bull., 47, 582-585, 2002.

Lui, P. C. and Tan, T. S.: Building integrated large-scale urban infrastructures: Singapore's experience, J. Urban Tech., 8, 49-68, doi:10.1080/10630730120052172, 2001.

MEI, Multivariate ENSO Index, Retrieved Jan 25, 2013, from http: //www.esrl.noaa.gov/psd/enso/mei/, 2013.

Meyssignac, B. and Cazenave, A.: Sea level: a review of present-day and recent-past changes and variability, J. Geodyn., 58, 96-109, doi:10.1016/j.jog.2012.03.005, 2012.

Meyssignac, B., Llovel, W., Becker, M., and Cazenave, A.: An assessment of two-dimensional past sea level reconstructions over 1950-2009 based on tide gauge data and different input sea level grids, Surv. Geophys., 33, 945-972, doi:10.1007/s10712-0119171-x, 2012a.

Meyssignac, B., Salas y Melia, D., Becker, M., Llovel, W., and Cazenave, A.: Tropical Pacific spatial trend patterns in observed sea level: internal variability and/or anthropogenic signature?, Clim. Past, 8, 787-802, doi:10.5194/cp-8-787-2012, 2012b.

Mitas, C. M. and Clement A.: Has the Hadley cell been strengthening in recent decades? Geophys. Res. Lett., L03809, doi:10.1029/2004GL021765, 2005.

Nerem, R. S., Chambers, D., Choe, C., and Mitchum, G. T.: Estimating mean sea level change from the TOPEX and Jason altimeter missions, Mar. Geod., 33, Supp 1, 435, doi:10.1080/01490419.2010.491031, 2010.
Nicholls, R. J. and Cazenave, A.: Sea-level rise \& it impact on coastal zones, Science, 328, 1517, Jun 18, doi:10.1126/science.1185782, 2010.

Pawlowicz, R., Beardsley, B., and Lentz, S.: Classical tidal harmonic analysis including error estimates in MATLAB using T_TIDE, Comp. Geosci., 28, 929-937, 2002.

PSMSL, Obtaining Tide Gauge Data, Retrieved Jan 25, 2013, from http://www.psmsl.org/data/obtaining/, 2013.

Qiu, B. and Chen, S.: Concurrent decadal mesoscale eddy modulations in the western North Pacific subtropical gyre, J. Phys. Oceanogr., doi:10.1175/JPO-D-12-0133.1, 2012.

Qu, T., Du, Y., Meyers, G., Ishida, A., and Wang, D.: Connecting the tropical Pacific with Indian Ocean through South China Sea, Geophys. Res. Lett., 32, L24609, doi:10.1029/2005GL024698, 2005.

Ray, R. and Douglas, B.: Experiments in reconstructing twentieth-century sea levels, Progr. Oceanogr., 91, 496-515, doi:10.1016/j.pocean.2011.07.021,, 2011.

Rong, Z., Liu Y., Zong, H., and Cheng, Y.: Interannual sea level variability in the South China Sea and its response to ENSO, Glob. Planet. Change, 55, 257-272, doi:10.1016/j.gloplacha.2006.08.001, 2007.

Simons, W. J. F., Socquet, A., Vigny, C., Ambrosius, B. A. C., Haji Abu, S., Promthong, C., Subarya, C., Sarsito, D. A., Matheussen, S., Morgan, P., and Spakman, W.: A decade of GPS in Southeast Asia: Resolving Sundaland motion and boundaries, J. Geophys. Res., 112, B06420, doi:10.1029/2005JB003868, 2007.

Tanaka, H. L., Ishizaki, N., and Kitoh, A.: Trend and interannual variability of Walker, monsoon and Hadley circulations defined by velocity potential in the upper troposphere, Tellus A, 56, 250269, 2004.

Timmermann, A., McGregor, S., and Jin, F. F.: Wind effects on past and future regional sea level trends in the southern Indo-Pacific, J. Clim., 23, 4429-4437, doi:10.1175/2010jclim3519.1, 2010.

Tkalich, P., Vethamony, P., Babu, M. T., and Malanotte-Rizzoli, P.: Storm surges in the Singapore Strait due to winds in the South China Sea, Nat. Hazards, doi:10.1007/s11069-012-0211-8, 2012.

Trenberth, K. E. and Hurrell, J. W.: Decadal atmosphereocean variations in the Pacific, Clim. Dyn., 9, 303-319, doi:10.1007/bf00204745, 1994.

Trisirisatayawong, I., Naeije, M., Simons, W., and Fenoglio-Marc, L.: Sea level change in the Gulf of Thailand from GPS-corrected tide gauge data and multi-satellite altimetry, Glob. Planet. Change, 76, 137-151, doi:10.1016/j.gloplacha.2010.12.010, 2011.

Tsimplis, M. N. and Shaw, A. G. P.: The forcing of mean sea level variability around Europe, Glob. Planet. Change, 63, 196-202, doi:10.1016/j.gloplacha.2007.08.018, 2008.

UHSLC, Research quality data Tanjong Pagar, Retrieved Jan 25, 2013 from http://ilikai.soest.hawaii.edu/uhslc/htmld/d0699A. html, 2013.

Unnikrishnan, A. S. and Shankar, D.: Are sea-level-rise trends along the coasts of the north Indian Ocean consistent with global estimates?, Glob. Planet. Change, 57, 301-307, doi:10.1016/j.gloplacha.2006.11.029, 2007.

Wannasingha, U., Webb, D. J., de Cuevas, B. A., and Coward, A. C.: On the Indonesian through-flow in the OCCAM model, Abstracts EGS-AGU-EUG Joint Assembly, Nice, France, 06-11 April, 2003. 
White, N. J., Church, J. A., and Gregory, J. M.: Coastal and global averaged sea level rise for 1950 to 2000, Geophys. Res. Lett., 32, L01601, doi:10.1029/2004GL021391, 2005.

Wolter, K. and Timlin, M. S.: Monitoring ENSO in COADS with a seasonally adjusted principal component index, Proc. 17th Climate Diagnostics Workshop, Norman, OK, NOAA/NMC/CAC, NSSL, Oklahoma Clim. Survey, CIMMS and School of Meteor., Univ. Oklahoma, 52-57, 1993.
Wolter, K. and Timlin, M.S.: Measuring the strength of ENSO events - how does 1997/98 rank?, Weather, 53, 315-324, doi:10.1002/j.1477-8696.1998.tb06408.x, 1998.

Yu, Z., Shen, S., McCreary, J. P., Yaremchuk, M., and Furue, R.: South China Sea throughflow as evidenced by satellite images and numerical experiments, Geophys. Res. Lett., 34, L01601, doi:10.1029/2006GL028103, 2007. 